Вісник Харківського національного університету імені В.Н. Каразіна Серія "Математика, прикладна математика і механіка" Том 93,2021 , с. $12-17$

УДК 519.216
Visnyk of V.N.Karazin Kharkiv National University Ser. "Mathematics, Applied Mathematics and Mechanics"

Vol. 93, 2021, p. 12-17

DOI: $10.26565 / 2221-5646-2021-93-02$

\title{
Speed of convergence of complementary probabilities on finite group
}

\author{
A. L. Vyshnevetskiy \\ Kharkiv National Automobile and Highway University, \\ 25 Yaroslava Mudrogo str., Kharkiv, 61002, Ukraine. \\ E-mail: alexwish50@gmail.com
}

Let $R G$ be a group algebra of a finite group $G$ over the field $R$ of real numbers. A probability $P(g)$ on the group $G$ corresponds to an element $p=\sum_{g} P(g) g \in R G$; we call it probability on the algebra $R G$. For a natural number $n, n$-fold convolution of probability $P$ on $G$ corresponds to $p^{n} \in R G$. Let $e \in R G$ be the probability that corresponds to the uniform probability $E(g)=|G|^{-1}(g \in G)$. Two probabilities $p, p_{1} \in R G$ are called complementary, if their convex linear combination equals to $e$, i.e. $\alpha p+(1-\alpha) p_{1}=e$ for some $\alpha, 0<\alpha<1$. We find condition for existence of such $\alpha$ and compare $\left\|p^{n}-e\right\|$ and $\left\|p_{1}{ }^{n}-e\right\|$ for arbitrary norm $\|$.$\| .$

Keywords: probability; finite group; convergence; convolution; group algebra.

Вишневецький О. Л. Швидкість збіжності додаткових ймовірностей на скінченній групі. Нехай $R G$ - групова алгебра скінченної групи $G$ над полем $R$ дійсних чисел. Імовірність $P(g)$ на групі $G$ відповідає елементу $p=\sum_{g} P(g) g \in R G$; ми називаємо їі ймовірністю на алгебрі $R G$. Для натурального числа $n, n$-кратна згортка ймовірності $P$ на $G$ відповідає $p^{n} \in R G$. Нехай $e \in R G$ - ймовірність, що відповідає рівномірній ймовірності $E(g)=|G|^{-1}(g \in G)$. Дві ймовірності $p, p_{1} \in R G$ називаються додатковими, якщо їх опукла лінійна комбінація дорівнює $e$, тобто $\alpha p+(1-\alpha) p_{1}=e$ для деякого $\alpha, 0<\alpha<1$. Ми знаходимо умови існування такого $\alpha$ і порівнюємо $\left\|p^{n}-e\right\|$ i $\left\|p_{1}{ }^{n}-e\right\|$ для довільної норми $\|$.$\| .$

Ключові слова: ймовірність; скінченна група; збіжність; групова алгебра.

Вишневецкий А. Л. Скорость сходимости дополнительных вероятностей на конечной группе. Пусть $R G$ - групповая алгебра конечной группы $G$ над полем $R$ вещественных чисел. Вероятность $P(g)$ на группе $G$ соответствует элементу $p=\sum_{g} P(g) g \in R G$; мы называем её вероятностью на алгебре $R G$. Для натурального числа $n, n$-кратная свертка вероятности $P$ на $G$ соответствует $p^{n} \in R G$. Пусть $e \in R G$ - вероятность, соответствующая равномерной вероятности $E(g)=|G|^{-1}(g \in G)$. Две вероятности $p, p_{1} \in R G$ называются дополнительными, если их выпуклая линейная комбинация равна $e$, т. е. $\alpha p+(1-\alpha) p_{1}=e$ для некоторого $\alpha, 0<\alpha<1$.

(c) A. L. Vyshnevetskiy, 2021 
Мы находим условия существования такого $\alpha$ и сравниваем $\left\|p^{n}-e\right\|$ и $\left\|p_{1}{ }^{n}-e\right\|$ для произвольной нормы $\|$.$\| .$

Ключевые слова: вероятность; конечная группа; сходимость; групповая алгебра.

2010 Mathematics Subject Classification: prim. 60B15, 60B10; sec. 20D99.

\section{Introduction}

Let $G$ be a finite group of order $|G|, R G$ the group algebra of the group $G$ over the field $R$ of real numbers. Each real function $F(g)$ on the group $G$ corresponds to an element $f=\sum_{g} F(g) g \in R G$ (we write $\sum_{g}$ instead of $\sum_{g \in G}$ ). We denote a function on the group $G$ with a capital letter and the corresponding element of $R G$ with the same (but small) letter, and call the latter a probability on $R G$. For instance, the trivial (uniform) probability $E(g)=\frac{1}{|G|}(g \in G)$ corresponds to the element

$$
e=\frac{1}{|G|} \sum_{g} g \in R G .
$$

Exploring probabilities on group algebras is sometimes more convenient than on groups (see e.g. [4])

Convolution of two functions $P, Q$ on $G$

$$
(P * Q)(h)=\sum_{g} P(g) Q\left(g^{-1} h\right) \quad(h \in G)
$$

corresponds to product $p q$ of corresponding elements $p, q \in R G$.

Let function $P(g)$ be a probability on a group $G$, i.e.

$$
P(g) \geq 0(g \in G), \sum_{g} P(g)=1
$$

and $P^{(n)}=P * \ldots * P(n$ times $)$ an $n$-fold convolution of function $P$. There is a lot of works devoted to evaluation of speed of convergence of $P^{(n)}$ to the uniform probability $E(g)$ on $G$ at $n \rightarrow \infty$ (see e.g. review [2]). In other words, a norm of $\left\|p^{n}-e\right\|$ is evaluated (for different norms) at $n \rightarrow \infty$. The case when $p^{n}=e$ for some finite $n$ was studied in [4]. Conditions for convergence $p^{n}$ to $e$ are well known, some refinements are in [3].

For any element $b=\sum_{g} b_{g} g \in R G$ we denote $|b|=\sum_{g}\left|b_{g}\right| \in R$. We write $b \geq 0$ if $b_{g} \geq 0$ for all $g \in G$. Now for any probability

$$
p=\sum_{g} a_{g} g
$$


on $R G$ conditions (1) can be written as follows:

$$
p \geq 0, \quad|p|=1
$$

Since $h \sum_{g} g=\sum_{g} g$ for any $h \in G$, then $h e=e$ and by linearity, we get $b e=|b| e$ for any element $b=\sum_{g} b_{g} g \in R G$. So

$$
p e=e
$$

for any probability $p \in R G$.

\section{Theorem}

We study the case when a linear combination of two probabilities on $R G$ equals to $e$. Since $|a|+|b|=|a+b|$ for any $a, b \in R G$, then from (3) this linear combination must be convex.

Convex linear combinations of idempotent distributions on countable groups were studied in [1])

Definition 1. Probabilities $p, p_{1} \in R G$ are called complementary, if their convex linear combination equals to e, i.e.

$$
\alpha p+(1-\alpha) p_{1}=e
$$

for some number $\alpha, 0<\alpha<1$.

We find out when for a given probability $p \in R G$ a complementary probability $p_{1} \in R G$ exists, i.e.

$$
p_{1}=\frac{e-\alpha p}{1-\alpha}
$$

is a probability for a number $\alpha, 0<\alpha<1$. By (3) we have to check if $p_{1} \geq 0$ and $\left|p_{1}\right|=1$. We also compare $\left\|p^{n}-1\right\|$ and $\left\|p_{1}^{n}-1\right\|$ ( $n$ is a natural number) for any norm $\|\cdot\|$.

Theorem 1. Let $p=\sum_{g} a_{g} g$ be a probability in algebra $R G, a=\max _{g \in G} a_{g}$. Then for any $\alpha, 0<\alpha \leq \frac{1}{a|G|}$ there exist a probability $p_{1} \in R G$ such that (5) holds. Moreover,

$$
\left\|p_{1}^{n}-e\right\|=\frac{1}{\left(\alpha^{-1}-1\right)^{n}}\left\|p^{n}-e\right\| .
$$

Proof. Let $p_{1}$ be as defined in (6). $p_{1} \geq 0$ if and only if $(1-\alpha) p_{1} \geq 0$. By (5)

$$
(1-\alpha) p_{1}=e-\alpha p=\sum_{g}\left(\frac{1}{|G|}-\alpha a_{g}\right) g .
$$


So $p_{1} \geq 0$ if and only if

$$
\sum_{g}\left(\frac{1}{|G|}-\alpha a_{g}\right) g \geq 0
$$

i.e.

$$
\frac{1}{|G|}-\alpha a_{g} \geq 0
$$

for any $g \in G$. It is equivalent to

$$
\alpha \leq \frac{1}{a|G|}
$$

where $a=\max _{g \in G} a_{g}$. This necessary condition for two complementary probabilities to exist is equivalent to the condition $p_{1} \geq 0$. Now we prove that $\left|p_{1}\right|=1$ :

$$
\left|(1-\alpha) p_{1}\right|=|e-\alpha p|=\sum_{g}\left(\frac{1}{|G|}-\alpha a_{g}\right)=\sum_{g} \frac{1}{|G|}-\alpha \sum_{g} a_{g}=1-\alpha|p|=1-\alpha
$$

i.e. $\left|p_{1}\right|=1$ (as $\left.\alpha \neq 1\right)$. So under condition (8) $p_{1}$ is a probability.

Now we compare $\left\|p^{n}-1\right\|$ and $\left\|p_{1}^{n}-1\right\|$ ( $\mathrm{n}$ is a natural number) for any norm $\|$.$\| . As well known, e$ is an idempotent of the algebra $R G: e^{k}=e$ for any natural number $k$. Taking into account the binomial formula, (4) and (6), we obtain:

$$
\begin{gathered}
(1-\alpha)^{n} p_{1}^{n}=(e-\alpha p)^{n}= \\
=e^{n}-C_{n}^{1} e^{n-1} \alpha p+C_{n}^{2} e^{n-2} \alpha^{2} p^{2}-\cdots+(-1)^{n} C_{n}^{n-1} e \alpha^{n-1} p^{n-1}+(-1)^{n} \alpha^{n} p^{n}= \\
=e\left(1-C_{n}^{1} \alpha+\cdots+(-1)^{n-1} C_{n}^{n-1} \alpha^{n-1}+(-1)^{n} \alpha^{n}-(-1)^{n} \alpha^{n}\right)+(-1)^{n} \alpha^{n} p^{n}= \\
=e(1-\alpha)^{n}+(-1)^{n} \alpha^{n}\left(p^{n}-e\right) .
\end{gathered}
$$

We divide by $(1-\alpha)^{n}$ :

$$
p_{1}^{n}=\frac{e(1-\alpha)^{n}+(-1)^{n} \alpha^{n}\left(p^{n}-e\right)}{(1-\alpha)^{n}}=e+\frac{(-1)^{n} \alpha^{n}}{(1-\alpha)^{n}}\left(p^{n}-e\right) .
$$

Then

$$
\left\|p_{1}^{n}-e\right\|=\left\|\frac{(-1)^{n} \alpha^{n}}{(1-\alpha)^{n}}\left(p^{n}-e\right)\right\|=\frac{\alpha^{n}}{(1-\alpha)^{n}}\left\|p^{n}-e\right\|=\frac{1}{\left(\alpha^{-1}-1\right)^{n}}\left\|p^{n}-e\right\| .
$$

The theorem is proved. It can be formulated as follows.

If $\alpha p+(1-\alpha) p_{1}=e$ for probabilities $p, p_{1} \in R G$ and some number $\alpha$, $0<\alpha<1$, then $\alpha \leq \frac{1}{a|G|}$, where $a=\max _{g \in G} a_{g}$ and equality (7) holds.

Corollary 1. If $a=\frac{2}{|G|}$, then $\left\|p_{1}^{n}-e\right\|=\left\|p^{n}-e\right\|$. 
Indeed, if $a=\frac{2}{|G|}$, one can put $\alpha=\frac{1}{2}$ in $(2.3)$.

Corollary 2. $p^{n}$ converges to e iff $p_{1}^{n}$ converges to e.

ORCID ID

A. L. Vyshnevetskiy (iD) https://orcid.org/0000-0003-1757-0416

\section{REFERENCES}

1. A. D. Bendikov, A. A. Grigor'yan, Ch. Pittet, W. Woess. Isotropic Markov semigroups on ultra-metric spaces, Russian Math. Surveys, 2014. - Vol. 69, No 4. - P. 589-680. https://doi.org/10.1070/RM2014v069n04ABEH004907

2. L. Saloff-Coste. Random walks on finite groups. In: H. Kesten (editor). Probability on Discrete Structures, Encyclopaedia of Mathematical Sciences (Probability Theory), - 2004. - Vol. 110. Springer, Berlin, Heidelberg, P. 263-340. https://link.springer.com/chapter/10.1007/978-3-662-09444-0_5

3. A. L. Vyshnevetskiy. Conditions of convergence of a random walk on a finite group, Colloquium Mathematicum. https://doi.org/10.4064/cm8196-5-2020

4. A. L. Vyshnevetskiy, E. M. Zhmud'. Random walks on finite groups converging after finite number of steps, Journal Algebra and Discrete Mathematics, 2008. - Vol. 7, No 2, - P. 123-129.

http://dspace.nbuv.gov.ua/handle/123456789/153370

\section{Швидкість збіжності додаткових ймовірностей на скінченній групі. \\ Вишневецький О. Л.}

Харківсъкий національний автомобільно-дорожний університет, вул. Ярослава Мудрого 25, Харків, Україна, 61002

Нехай функція $P \in$ ймовірністю на скінченній групі $G$, тобто $P(g) \geq 0$ $(g \in G), \sum_{g} P(g)=1$ (ми пишемо $\sum_{g}$ замість $\left.\sum_{g \in G}\right)$. Згортка двох функцій $P, Q$ на групі $G \in(P * Q)(h)=\sum_{g} P(g) Q\left(g^{-1} h\right) \quad(h \in G)$. Нехай $E(g)=\frac{1}{|G|} \sum_{g} g \in$ рівномірною (тривіальною) ймовірністю на групі $G, P^{(n)}=P * \ldots * P(n$ разів $)-n$ -кратна згортка $P$. За добре відомої нескладної умови ймовірність $P^{(n)}$ збігається до $E(g)$ при $n \rightarrow \infty$. Багато робіт присвячено оцінці швидкості цієї збіжності для різних норм. Будь-яка ймовірність (i, загалом, будь-яка функція зі значеннями в полі $R$ дійсних чисел) на групі може бути пов'язана з елементом групової алгебри цієї групи над полем $R$. Це можна зробити наступним чином. Нехай $R G$ - групова алгебра скінченної групи $G$ над полем $R$. Ймовірність $P(g)$ на групі $G$ відповідає елементу $p=\sum_{g} P(g) g$ алгебри RG. Ми позначаємо функцію на групі $G$ великою 
літерою, а відповідний елемент з $R G$ тією ж (але малою) літерою, і останній називаємо ймовірністю на $R G$. Наприклад, рівномірна ймовірність $E(g)$ відповідає елементу $e=\frac{1}{|G|} \sum_{g} g \in R G$. Згортка двох функцій $P, Q$ на $G$ відповідає добутку $p q$ відповідних елементів $P, Q$ в груповій алгебрі $R G$. Для натурального числа $n$, $n$-кратна згортка ймовірності $P$ на $G$ відповідає елементу $p^{n} \in R G$. У статті ми вивчаємо випадок, коли лінійна комбінація двох ймовірностей в алгебрі $R G$ дорівнює ймовірності $e \in R G$. Така лінійна комбінація повинна бути опуклою. Точніше, ми співставляємо ймовірності $p \in R G$ іншу ймовірність $p_{1} \in R G$ наступним чином. Дві ймовірності $p, p_{1} \in R G$ називаються додатковими, якщо їх опукла лінійна комбінація дорівнює $e$, тобто $\alpha p+(1-\alpha) p_{1}=e$ для деякого числа $\alpha, 0<\alpha<1$. Ми знаходимо умови існування такого $\alpha$ і порівнюємо $\left\|p^{n}-e\right\|$ та $\left\|p_{1}^{n}-e\right\|$ для довільної норми $\|$.$\| .$

Ключові слова: ймовірність; скінченна група; збіжність; згортка; групова алгебра.

\section{Speed of convergence of complementary probabilities on finite group. \\ A. L. Vyshnevetskiy \\ Kharkiv National Automobile and Highway University, 25 Yaroslava Mudrogo str., Kharkiv, 61002, Ukraine}

Let function $P$ be a probability on a finite group $G$, i.e. $P(g) \geq 0 \quad(g \in G), \sum_{g} P(g)=1$ (we write $\sum_{g}$ instead of $\sum_{g \in G}$ ). Convolution of two functions $P, Q$ on group $G$ is $(P * Q)(h)=\sum_{g} P(g) Q\left(g^{-1} h\right) \quad(h \in G)$. Let $E(g)=\frac{1}{|G|} \sum_{g} g$ be the uniform (trivial) probability on the group $G, P^{(n)}=P * \ldots * P$ (n times) an $n$-fold convolution of $P$. Under well known mild condition probability $P^{(n)}$ converges to $E(g)$ at $n \rightarrow \infty$. A lot of papers are devoted to estimation the rate of this convergence for different norms. Any probability (and, in general, any function with values in the field $R$ of real numbers) on a group can be associated with an element of the group algebra of this group over the field $R$. It can be done as follows. Let $R G$ be a group algebra of a finite group $G$ over the field $R$. A probability $P(g)$ on the group $G$ corresponds to the element $p=\sum_{g} P(g) g$ of the algebra RG. We denote a function on the group $G$ with a capital letter and the corresponding element of $R G$ with the same (but small) letter, and call the latter a probability on $R G$. For instance, the uniform probability $E(g)$ corresponds to the element $e=\frac{1}{|G|} \sum_{g} g \in R G$. The convolution of two functions $P, Q$ on $G$ corresponds to product $p q$ of corresponding elements $p, q$ in the group algebra $R G$. For a natural number $n$, the $n$-fold convolution of the probability $P$ on $G$ corresponds to the element $p^{n} \in R G$. In the article we study the case when a linear combination of two probabilities in algebra $R G$ equals to the probability $e \in R G$. Such a linear combination must be convex. More exactly, we correspond to a probability $p \in R G$ another probability $p_{1} \in R G$ in the following way. Two probabilities $p, p_{1} \in R G$ are called complementary if their convex linear combination is $e$, i.e. $\alpha p+(1-\alpha) p_{1}=e$ for some number $\alpha, 0<\alpha<1$. We find conditions for existence of such $\alpha$ and compare $\left\|p^{n}-e\right\|$ and $\left\|p_{1}{ }^{n}-e\right\|$ for an arbitrary norm $\|\cdot\|$.

Keywords: probability; finite group; convergence; convolution; group algebra.

Article history: Received: 11 February 2021; Final form: 27 May 2021; Accepted: 9 June 2021. 